\title{
PENGARUH AUDIT INTERNAL TERHADAP PENGGUNAAN SISTEM AKUNTANSI MANAJEMEN DAN DAMPAKNYA PADA KINERJA PERUSAHAAN (SURVEY PADA BUMN DI INDONESIA)
}

\author{
Muhammad Dahlan \\ Fakultas Ekonomi dan Bisnis (FEB) Universitas Padjadjaran Bandung \\ E-mail: dahlanm2004@yahoo.com
}

\begin{abstract}
Abstrak. Studi empiris ini bertujuan untuk menguji pengaruh audit internal terhadap penggunaan sistem akuntansi manajemen dan dampaknya pada kinerja perusahaan. Penelitian ini menggunakan kuesioner sebagai media dalam pengumpulan dan pengiriman kuesioner menggunakan jasa pos kepada 149 perusahaan BUMN di Indonesia. Hasil yang diperoleh tingkat responsi pengembalian adalah sebanyak 85 kuesioner (57,05\%). Pengujian hipotesis menggunakan alat analisis path. Hasil pengujian menunjukkan audit internal dan penggunaan sistem akuntansi manajemen (SAM) berpengaruh positif terhadap kinerja perusahaan. Selanjutnya audit internal juga berpengaruh positif terhadap penggunaan (SAM) dan dampaknya pada kinerja perusahaan. Hal ini terjadi karena auditor internal dan akuntan manajemen berperan aktif dalam meningkatkan efektivitas dari pada sistem pengawasan intern, penegakan hukum, tata kelola perusahaan yang baik, risiko sistem pengendalian manajemen, sistem akuntansi keuangan, sistem akuntansi manajemen, dan seterusnya berdampak pada efektivitas pencapaian tujuan organisasi diantaranya seperti peningkatan kepuasan pelanggan, perencanaan manajemen dan supervisi operasionalnya.
\end{abstract}

Keywords: Firm Performance, Management Accounting System, Internal Audit, and Usefullness of Management Accounting Systems.

\section{THE EFFECT OF INTERNALAUDIT ON USEFULNESS OF MANAGEMENT ACCOUNTING SYSTEM AND ITS IMPACT TO FIRM PERFORMANCE (A SURVEY AT BUMN IN INDONESIA)}

Abstract. This study is empirical examined the effect of internal audit on usefulness of management accounting system and its impact to firm performance. Mail survey were used for questionnaires distributed to 149 statedowned enterprise in Indonesia and from the responses rate of 85 company's (57,05\%) were hyphotesis test using path analysis. The result indicated that internal audit and usefulness of management accounting system (MAS) was found a positive effect on firm performance. The internal audit indicated too a positive effect on usefulness of MAS and its impact to firm performance. Because the roles of internal auditors and management accountants will be improved the effectiveness of internal control system, law enforcement, good corporate governance, risk of management contoll system, financial accounting system, management accounting system and management information system, and its impact to organization's objectives are effectively achieved include increase of the customer satisfaction, management planning and operation supervising.

Keywords: Firm Performance, Management Accounting System, Internal Audit, and Usefullness of Management Accounting Systems.

\section{PENDAHULUAN}

Dalam kontek pengelolaan perusahaan yang baik dan bermartabat, keterbukaan dan akuntabilitas informasi baik untuk pemegang saham maupun manajemen untuk pengambilan keputusan bisnis dipandang perlu memiliki informasi dan akses yang cukup kedalam perusahaan agar tujuan dan pengelolaan perusahaan dapat berjalan sebagaimana seharusnya (Daniri, 2005). Merujuk kepada agency theory mengilustrasikan bahwa agen atau manajemen sebagai pengelola perusahaan seharusnya mendapatkan pengewasan internal yang memadai (misalnya oleh auditor internal) sebagai konsultan dan pendeteksian dini terhadap resiko sehingga resiko dapat dminimalkan. Karena manajemen perusahaan sebagai agent dikhawatirkan akan bertindak dengan penuh kesadaran bagi kepentingannya sendiri, bukan sebagai pihak yang arif dan bijaksana serta adil terhadap pemegang saham sebagaimana diasumsikan dalam stewardship theory. Apakah selalu demikian sehingga satuan pengewas intern harus ada agar organ-organ perusahaan akan berjalan sebagaimana mestinya.

Hal ini sejalan dengan fungsi audit internal yaitu untuk meningkatkan nilai operasi, terwujudnya tata kelola perusahaan yang baik, memastikan bahwa manajemen telah menggunakan sumber daya perusahaan yang ekonomis dan efisien serta semua peraturan yang berlaku telah dilaksanakan dengan baik agar efektivitas pencapaian tujuan perusahaan dapat terwujud (IIA, 2011dan Ratliff, et al.1996). Artinya keberadaan audit internal untuk membantu manajemen baik sebagai peneydia informasi seperti laporan hasil audit dan rekomendasinya maupun sebatas mengingatkan manajemen agar selalu law enforcement, menjungjung tinggi sikap kehati-hatian, governance process dan fairness.

Namun, berbeda dengan contoh kasus PT. Great River International tbk, sampai dengan tahun 2004 perusahaan ini masih mencatatkan laba yang layak secara bisnis dan aktivitas korporasi berjalan normal, akan tetapi haluan yang dituju perusahaan tidak jelas. Hal ini terbukti dengan mencuatnya skandal keuangan yang menimpanya seperti gagal bayar hutang dan kesulitan arus kas. Ini sebagai akibat dari kurang berfungsinya organ-organ perusahaan misalnya dewan komisaris dan audit internal sebagai pengawas intern perusahaan (Bachtiar, 2012). Kinerja korporasi baik dan terus tumbuh namun kebijakan manajemen tidak menguntungkan perusahaan. Seakan-akan 
manajemen tidak memiliki informasi yang akurat, relevan dan terkini untuk mengetahui bagaimana kondisi keuangan dan operasional perusahaan yang sebenarnya saat ini, sehingga banyak kebijakan dan keputusan yang diambil tidak mampu memperbaiki kesulitan keuangan perusahaan. Begitu juga halnya peran akuntan manajemen sebagai penyedia informasi bagi manajemen (information provider) boleh dikata hampir tidak ada wujudnya diperusahaan publik ini. Apakah komunikasi antar organ perusahaan yang ada begitu pentingnya bisa-bisa manajemen korporasi menjadi hilang kendali mengurus perusahaan. Adakah keharusan auditor internal menegur dan menyediakan informasi bagi manajemen.

Semestinya sistem informasi akuntansi manajemen perusahaan yang baik mampu memproses semua transaksi keuangan dan non-keuangan menjadi informasi (output) yang kemudian disajikan dan dipergunakan oleh manajemen untuk keperluan perencanaan, pengendalian, continuous improvement, coordinate product design, production, penilaian kinerja dan pengambilan keputusan agar pengelolaan menjadi lebih objektif dan akuntabel (Hansen dan Mowen, 2005; Horngren, et al. 2012). Kemudian audit internal juga mampu menyediakan berbagai laporan hasil audit dan rekomendasi perbaikan dimasa akan datang untuk membantu manajemen mendeteksi resiko, menyusun perencanaan, penagawasan dan penilaian kinerja dengan tujuan untuk memajukan perusahaan yang lebih baik dan profesional (IIA, 2011 dan Elder, et al. 2012). Pendapat ini menggambarkan bahwa para pakar akuntansi manajemen dan pengawasan intern menyakini apabila konsep akuntansi manajemen dan pengawasan intern diterapkan dengan baik dan konsisten maka bisa membantu dan mengawasi perilaku manajemen dalam mengelola perusahan agar perusahaan dapat mencapai tujuannya sesuai yang diinginkan semua pihak.

Beradasarkan uraian diatas dapat disimpulkan bahwa disatu sisi menyatakan audit internal dan penggunaan sistem akuntansi manajemen (usefulness of management accounting systems) mampuni membantu dan menyediakan informasi bagi manajemen untuk keperluan perencanaan, pengendalian, penilaian kinerja dan pengambilan keputusan sehingga perusahaan akan terus beroperasi sesuai dengan tujuan yang ditetapkan. Ini menunjukkan bahwa audit internal (satuan pengawas intern) dan penggunaan sistem akuntansi manajemen (SAM) dapat diartikan sebagai dewa penyelamat dan pembantu setia manajemen dalam mengarungi jalannya operasional perusahaan.

Disisi yang lain menunjukkan bahwa satuan pengawas intern dan penggunaan sistem akuntansi manajemen (usefulness of management accounting systems) diasumsikan tidak dapat diandalkan lagi karena baik rekomendasi hasil pemeriksaan dan informasi yang tersedia kurang mencerminkan kondisi saat ini sehingga manajemen perusahaan memilih jalannya sendiri agar kebijakan dan keputusan yang diambil tepat sasaran (Bachtiar, 2012 dan Bahaudin,
2011). Kadang kala manajemen puncak lebih percaya pada intuisi yang dibangunnya sendiri dari pada informasi dan rekomendasi dari bawahannya. Namun kenyataannya justru memperburuk kondisi keuangan dan operasional perusahaan sebagai akibat dari kebijakan dan keputusan yang diambil kurang berdasar. Sukar untuk menolak kedua sisi tersebut karena memiliki kekuatan argumentasi yang sama sehingga menarik untuk diteliti lebih lanjut sisi mana yang seharusnya layak untuk dipertahankan.

Mengacu kepada research motivation dan research question diatas, maka penulis tiba saatnya mencoba menyatakan perumusan masalah dan ingin tahu lebih dalam lagi yaitu: (1) apakah audit internal dan penggunaan sistem akuntansi manajemen (usefulness of management accounting systems) berpengaruh terhadap kinerja perusahaan, dan (2) apakah audit internal berpengaruh terhadap penggunaan sistem akuntansi manajemen (usefulness of management accounting systems) dan dampaknya pada kinerja perusahaan.

Berdasarkan uraian diatas maka tujuan penelitian (research objectives) ini antara lain yaitu: (1) untuk mengetahui apakah audit internal dan penggunaan sistem akuntansi manajemen (usefulness of management accounting systems) berpengaruh terhadap kinerja perusahaan, dan (2) untuk mengetahui apakah audit internal berpengaruh terhadap penggunaan sistem akuntansi manajemen (usefulness of management accounting systems) dan dampaknya pada kinerja perusahaan.

\section{Pengaruh Audit Internal Terhadap Kinerja Perusahaan}

Hasil penelitian terdahulu menunjukkan audit internal berpengaruh terhadap pencapaian dan peningkatan kinerja perusahaan (Barry, et al. 1994; Glover, et al. 1998; dan Holzinger, 1999). Satuan pengawas intern dapat membantu manajemen melalui laporan hasil audit internal beserta rekomendasinya. Laporan hasil audit merupakan masukan kepada manajemen misalnya kondisi operasional dan tingkat resiko perusahaan saat ini. Manajemen menindaklanjuti dengan melakakun analisis dan pendalaman lebih lanjut serta mempelajari sehingga menerbitkan berbagai kebijakan agar resiko tersebut dapat diminimalkan yang pada akhirnya operasional perusahaan akan berjalan sesuai dengan rencana dan nantinya akan meningkatkan kinerja.

Selanjutnya, menurut Maher dan Ramanan (1988) menjelaskan the result of a study reveal a statistically significant and positive effect of the internal audit on managerial performance. Kemudian menurut Lane (1983) with the operational audit, a firm effectiveness is systematically appraised for the degree to which it meets corporate and industry standards. Audit internal memastikan manajemen telah menggunakan sumber daya perusahaan yang ekonomis dan efisien serta menjamin pelaksanaan peraturan yang berlaku telah dipenuhi agar efektifitas pencapaian tujuan perusahaan terwujud sehingga target kinerja 
tercapai. Begitu juga hasil penelitian Zarkasyi (2007) significant and positive effect of the internal audit on state-owned enterprise performance. Pada umumnya BUMN yang menerapkan satuan pengarwas intern (audit internal) yang efektif dalam bidang keuangan dan operasional menunjukkan target-target program kerja senantiasa dapat tercapai, tentunya akan mempengaruhi pencapaian kinerja perusahaan.

Hasil penelitian tersebut sejalan dan mendukun pendapat yang diyatakan oleh IIA (2011) dan Elder, et al. (2012) audit internal melakukan pengawasan dan mereviu untuk menentukan apakah resiko manajemen, kebijakan yang diambil, prosedur kerja, sistem pengawasan intern dan catatan akuntansi sudah sesuai dengan standard dan peraturan yang ada, dilakukann oleh auditor internal yang independen dan kompeten untuk meyakini tujuan perusahaan tercapai. Dengan kata lain, jika tujuan perusahaan telah tercapai yang pada akhirnya akan berpengaruh pada kinerja perusahaan meningkat.

Menurut Ratliff, et al. (1996) dan Sawyers dan Dittenhover ( 2003) audit internal berguna bagi manajemen dalam hal pengawasan operasional misalnya untuk menyakini operasi sesuai aturan yang berlaku; untuk menyakini program-program kerja perusahaan dilaksanakan sesuai prinsip-prinsip yang ekonomis, efisien dan efektif; untuk meyakini pengawasan internal efektif agar resiko manajemen dapat dikurangi; dan untuk meyakini tata kelola perusahaan berjalan sebagaimana mestinya, dengan harapan pada akhirnya kinerja perusahaan dapat meningkat. Oleh karena itu, hipotesis ini dinyatakan seperti berikut.

H1: Terdapat pengaruh audit internal terhadap kinerja perusahaan

\section{Pengaruh Audit Internal Terhadap Pengunaan Sistem Akuntansi Manajemen (SAM)}

Hasil penelitian Zeigenfuss, et al. (1994) dan Crockett (1988) menunjukkan audit internal berpengaruh terhadap penggunaan sistem akuntansi manajemen. Menurut Ziegenfuss, et al. (1994) the internal audit have been positive effect on usefulness of management accounting system". Crockett (1988) mengungkapkan bahwa the internal audit and internal audit director can cooperation during operational audit by providing audit report influence on management accounting system. Kemudian menurut Kusmayadi (2005) hasil penelitiannya menyatakan bahwa audit operasional berpengaruh terhadap penerapan sistem akuntansi manajemen (SAM).

Audit internal menghasilkan laporan temua hasil audit dan rekomendasi untuk ditindaklanjuti. Laporan temuan ini merupakan masukan dan informasi misalnya berupa informasi timeliness dan aggregation akuntansi manajemen yang berguna bagi manajemen. Manajemen melalui penggunaan laporan temuan audit bisa mengetahui kondisi dan permasalahan yang ada dilapangan seterusnya perlu tidaknya perbaikan-perbaikan baik di sistem keuangan maupun di sistem operasi. Dengan demikian laporan hasil audit mengandung berbagai informasi bagi manajemen baik informasi keuangan maupun non-keuangan. Dengan kata lain, audit internal berpengaruh terhadap penggunaan sistem akuntansi manajemen. Sistem akuntansi manajemen mencakup mulai dari perencanaan, pengendalian sampai dengan pengambilan keputusan baik dibidang keuangan maupun non-keuangan (Horngren et al., 2012).

Selanjutnya, IIA (2011) dan Horngren, Sundem dan Stratton (1996) menjelaskan fungsi audit internal berdampak positif terhadap penerapan sistem akuntansi manajemen yaitu dengan melakukan pengawasan, penilaian dan reviu untuk menentukan tingka resiko operasi, keandalan kebijakan yang diambil, kesesuaian prosedur kerja, efektivitas sistem pengawasan intern dan keakuratan catatan akuntansi sesuai dengan standard dan peraturan yang ada. Menilai dan meyakini bahwa manajemen telah menggunakan sumber dayanya secara ekonomis dan efisien serta memastikan efektivitas pencapaian tujuan. Laporan hasil audit berupa laporan temuan dan saran perbaikan kepada manajemen untuk ditindaklanjuti berguna bagi manajemen sebagai masukan yang mendukung pengambilan keputusan. Dengan kata lain, audit internal berpengaruh terhadap perbaikan, penerapan dan kelangsungan berjalannya sistem akuntansi manajemen.

Audit internal dapat menyediakan informasi keuangan dan informasi kondisi operasional perusahaan sehingga membantu manajemen dalam pengelolaan perusahaan, audit internal melakukan reviu sistem pengendalian intern, ekonomisasi, efisiensi dan efektivitas pencapaian tujuan perusahaan, mereviu efektivitas proses pelaksanaan tata kelola perusahaan yang baik dan pengendalian resiko sehingga pertanggungjawan pengelolaan operasi menjadi transparan dan akurat (Ratliff, et al. 1996 dan Sawyer dan Dittenhover, 2003). Audit internal juga membantu manajemen dalam hal penyediaan informasi yaitu laporan cash opname, laporan stock opname, laporan inventarisasi phisik aktiva tetap, laporan audit triwulanan, tahunan dan reviu laporan keuangan serta laporan audit khusus. Laporanlaporan audit ini menyediakan berbagai informasi diantaranya informasi timeliness, aggregation dan integration akuntansi manajemen (Horngren, et al. 2012; Chenhall dan Morris, 1986). Oleh karena itu, penulis berkeyakinan dengan hipotesis berikut ini yaitu:

H2: Terdapat pengaruh audit internal terhadap penggunaan sistem akuntansi manajemen (usefulness of management accounting systems)

\section{Pengaruh Pengunaan sistem akuntansi manajemen (SAM) Terhadap Kinerja Perusahaan}

Hasil penelitian terdahulu tentang akuntansi manajemen menunjukkan bahwa penggunaan sistem akuntansi manajemen berpengaruh terhadap peningkatan kinerja perusahaan (Soobaroyen dan Poorundersing, 2008 dan Duh, et al. 2009). Penerapan 
sistem akuntansi manajemen yang baik dan konsisten akan memberikan manfaat yang besar bagi manajemen misalnya tersedianya informasi yang akurat, akuntabel dan relevan, manajemen memperoleh masukan tentang kondisi operasional perusahaan saat ini, mengetahui tingkat resiko dan bagaimana meminimalkannya, dan sebagainya. Keadaan ini akan membawa perubahan dalam operasional perusahaan yang akhirnya berdampak pada kinerja perusahaan. Dengan kata lain, menurut Soobaroyen dan Poorundersing (2008) karakteristik-karakteristik informasi akuntansi manajemen (misalnya informasi broadscope, timeliness, aggregation dan integration) berpengaruh positif dan signifikan terhadap kinerja manajerial. Kemudian penerapan sistem akuntansi manajemen yang baik dan konsisten berdampak positif terhadap peningkatan kinerja perusahaan (Duh, et al. 2009).

Selanjutnya, berdasarkan kajian dari beberapa buku teks juga menjelaskan bahwa penggunaan sistem akuntansi manajemen akan membantu manajemen dalam hal peneydiaan informasi sehingga membantu dan mendorong karyawan dan manajer untuk berkerja yang lebih baik agar tujuannya dapat tercapai. Tersedianya informasi yang akurat, akuntabel dan relevan mendukung manajemen untuk perencanaan, pengendalian, penilaian kinerja dan pengambilan keputusan sehingga kinerja perusahaan meningkat (Horngren, Datar dan Rajan, 2012; Brandon dan Drtina, 1997). Selanjutnya, menurut Hoque (2004) akuntansi manajemen merupakan sistem yang rasional dalam hal penyediaan informasi okonomi dan non-okonomi yang mendukung koordinasi operasional dan pengambilan keputusan yang tepat sasaran sehingga promosi, nama baik perusahaan dan pencapaian tujuan perusahaan dapat dilaksanakan secara efisien dan efektif.

Brandon dan Drtina (1997) menjelaskan bahwa tujuan sistem akuntansi manajemen adalah menyediakan informasi untuk membantu manajer agar tujuan perusahaan dapat tercapai sesuai dengan yang ditetapkan sebelumnya. Kemudian beliau menambahkan bahwa informasi akuntansi manajemen juga dapat meningkatkan motivasi bawahan untuk meningkatkan kinerjanya sehingga kinerja perusahaan ikut meningkat. Artinya manajemen menggunakan informasi akuntansi manajemen untuk pengambilan keputusan. Pengambilan keputusan yang didukung oleh informasi yang relevan dan akurat dapat diyakini bahwa nantinya kinerja perusahaan akan meningkat, sehingga dapat dikatakan penggunaan sistem akuntansi manajemen (usefulness of managenent accounting system) berpengaruh terhadap kinerja perusahaan. Maka hipotesis berikutnya yaitu:

H3 : Terdapat pengaruh penggunaan sistem akuntansi manajemen terhadap kinerja perusahaan.

\section{METODE}

Pengumpulan Data dan Pemilihan Sampel Penelitian

Populasi penelitian adalah perusahaan Badan Usaha Milik Negara (BUMN) yang berdomisili di pulau Jawa dan di luar pulau Jawa yang berbadan hukum PT atau Persero dan Perum, karena memiliki akuntabilitas pertangganggungjawaban pelaporan relatif tinggi. Kenapa BUMN karena memiliki anggaran operasional Rp.1.100,00 triliun lebih dan menguasai aset mencapai Rp.2.500,00 triliun (Abubakar, 2011). Jumlah aset yang besar bisa mewakili sebagian dari aktivitas bisnis secara nasional. Berdasarkan laporan Kementerian BUMN 2012, perusahaan milik Negara baik berbentuk persero dan perum sebanyak 149 perusahaan. Rincian populasi disajikan dalam tabel 1 dibawah ini.

\section{Tabel 1: Populasi Penelitian}

Sumber: Kementerian BUMN 2012.

Pengumpulan data menggunakan kuesioner yang disusun dalam bentuk pertanyaan dengan kategori 7 skala Likert. Mengacu kepada entitas BUMN yang ada, ditetapkan unit analisis penelitian adalah perusahaan BUMN. Unit analisis ini kemudian dikirim 1 buah kuesioner menggunakan jasa pengiriman (Mail Survey) yang ditujukan kepada manajer (level menegah dan puncak) yang diwikili

\begin{tabular}{clc}
\hline No & \multicolumn{1}{c}{ Kelompok Sektor Industri } & Jumlah \\
\hline I & $\begin{array}{l}\text { Sektor Industri dan Perdagangan } \\
\text { Sektor Kawasan Industri, Jasa Konstruksi }\end{array}$ & 23 \\
II & $\begin{array}{l}\text { Sekn Konsultan Konstruksi } \\
\text { dan }\end{array}$ \\
III $\begin{array}{l}\text { Sektor Perhubungan, Telekomunikasi dan } \\
\text { Pariwisata }\end{array}$ & 20 \\
IV $\begin{array}{l}\text { Sektor Pertanian, Perkebunan dan } \\
\text { Kehutanan }\end{array}$ & 23 \\
V & $\begin{array}{l}\text { Sektor Pelayanan Umum } \\
\text { VI }\end{array}$ & 13 \\
Vektor Keuangan, Asuransi dan Jasa & 39 \\
\multicolumn{2}{l}{\begin{tabular}{l} 
Jumlah \\
\hline
\end{tabular}}
\end{tabular}

oleh Direktur Keuangan atau Direktur Operasi (Produksi) atau Direktur Pemasaran atau manajer, yang selanjutnya disebut sebagai responden penelitian atau unit obsevasi. Berdasarkan kuesioner yang kembali setelah disortir dan diteliti keabsahannya ditetapkan sebanyak 85 buah kuesioner (57,05\%) siap diolah.

\section{Definisi dan Pengukuran Variabel}

Operasionalisasi variabel. Audit internal adalah aktivitas konsultasi yang dirancang dan menjamin independen dan objektif untuk menambah nilai dan meningkatkan operasi sehingga dapat membantu dan menjembatani manajemen dalam pencapaian tujuan perusahaan, evaluasi dan meningkatkan efektivitas pengendalian resiko dan proses tatakelola yang baik sehingga penggunaan sumber daya yang ekonomis dan efisien, memastikan manajemen telah melaksanakan semua peraturan yang berlaku dan memastikan efektivitas pencapaian tujuan perusahaan telah tercapai (IIA, 2011). Audit internal diwakili oleh variabel $\mathrm{X}$.

Variabel audit internal merupakan variabel independen yang diukur dengan menggunakan empat dimensi yaitu dimensi evaluasi sitem pengendalian intern, ekonomisasi, efisiensi dan efektivitas 
pencapaian tujuan operasional perusahaan, yang dikembangkan oleh Ratliff, et al. (1996); IIA (2011) dan Sawyers dan Dittenhover (2003). Untuk setiap indikator telah diuji validitas dan reliabilitasnya oleh Pratolo (2006) dengan hasil valid dan reliabel. Kemudian untuk setiap indikator yang ada dikembangkan lagi tetapi tetap relevan dengan aslinya. Uraian lengkap dimensi audit internal seperti berikut:

a. Dimensi evaluasi sistem pengendalian intern (internal control systems). Jawaban atas pertanyaan apakah manajemen telah melaksanakan sistem dan prosedur pengendalian operasional perusahaan yang baik dan handal seperti sistem pembagian tugas dan fungsi karyawan, sistem penerimaan dan pengeluaran, sistem pencatatan dan pelaporan, sistem pengendalian risiko dan kepatuhan kepada kebijakan dan peraturan yang ada/berlaku.

b. Dimensi evaluasi ekonomisasi (cost of operations). Jawaban atas pertanyaan apakah manajemen perusahaan telah melaksanakan tugas dan tanggungjawabnya secara hemat menggunakan sumber daya yang ada dengan kuantitas dan kualitas yang sesuai, pada saat yang tepat dan pada biaya yang rendah seperti praktik pengadaan barang dan jasa, penggunaan sumber daya yang ada selalu mempertimbangkan azas manfaat.

c. Dimensi evaluasi efisiensi (method of operations). Jawaban atas pertanyaan apakah manajemen perusahaan melaksanakan tugas dan tanggungjawabnya dengan usaha maksimum dan belanja yang minimum misalnya memaksimalkan output atau input diminimalkan untuk mencapai kualitas dan kuantitas output tertentu dengan cara sistem operasi handal dan sistem penyusunan program kerja yang digunakan saat ini sudah efisien.

d. Dimensi evaluasi efektivitas (results of operations). Jawaban atas pertanyaan apakah manajemen perusahaan telah memperoleh hasil atau manfaat sesuai dengan kriteria yang ditetapkan, misalnya pencapaian tujuan atau program kerja perusahaan baik tujuan internal maupun eksternal.

Selanjutnya, penggunaan sistem akuntansi manajemen (usefulness of management accounting systems) diwakili oleh variabel Y yaitu seberapa besar manfaat informasi yang disajikan tersebut berguna bagi manajemen untuk perencanaan, pengendalian, penilaian kinerja dan pengambilan keputusan dan seberapa baik sistem informasi akuntansi manajemen mampu membantu dan memotivasi karyawan dan manajer untuk berkerja dengan lebih baik dan manfaat informasi harus lebih besar dibandingkan biaya yang dikeluarkan untuk mendapatkan informasi tersebut (Berkaoui, 2002; Horngren, et al. 2012).

Variabel Y merupakan variabel independen kedua yang diukur dengan menggunakan karakteristik informasi akuntansi manajemen yang dikembangkan oleh Chenhall dan Morris (1986) dan telah diuji validitas dan reliabilitasnya oleh Chenhall dan Morris (1986) dan Soobaroyen dan Poorundersing (2008) dengan hasil valid dan reliabel. Variabel ini menggunakan empat dimensi yaitu informasi Broadscope, Timeliness, Levels of Aggregation dan Integrative Nature dengan uraian seperti berikut:

a. Dimensi cakupan luas dan orientasi masa akan datang (Broad Scope). Informasi skop merupakan informasi yang disajikan mulai dari yang sederhana sampai dengan yang kompleks misalnya informasi orientasi masa akan datang, probabilistik, nonekonomi, eksternal dan informasi non-keuangan.

b. Dimensi ketepatan waktu dan sesuai kebutuhan pengguna (Timeliness). Informasi tepat waktu merupakan informasi yang disajikan sesuai kebutuhan pengguna internal, cepat dan sesuai permintaan misalnya informasi diterima sesuai permintaan, diterima otomatis, dan diterima per periodik.

c. Dimensi pengumpulan (Levels of Aggregation). Informasi agregasi merupakan informasi yang disajikan secara menyeluruh, ringkas dan mendetail misalnya informasi berdasarkan departemen, mempengaruhi periode berjalan, mempengaruhi departemen lainnya dan informasi berdasarkan biaya tetap dan variabel.

d. Dimensi terintegrasi (Integrative Nature). Informasi integrasi merupakan informasi yang disajikan secara terintegrasi, informasi satu bagian dapat diakses di bagian yang lainnya misalnya informasi yang mempengaruhi pengambilan keputusan antar bagian, informasi target aktivitas bagian tertentu dan informasi yang mempengaruhi pengambilan keputusan kinerja bagian yang bersangkutan.

Kinerja perusahaan merupakan variabel dependen yang diwakili oleh variabel Z. Menurut Robbins dan Coulter (2009) kinerja adalah hasil akhir dari suatu aktivitas. Beliau menambahkan kinerja perusahaan dapat diukur dengan menggunakan tiga dimensi yaitu: produktivitas, efektivitas dan ranking perusahaan. Sedangkan Govindarajan (1984) dan Bisbe dan Otley (2004) menyatakan bahwa kinerja perusahaan dapat diukur dengan menggunakan data keuangan dan non-keuangan. Kemudian menurut Gul (1991) dan Soobaroyen dan Poorundersing (2008) pengukuran kinerja dapat diukur dengan menggunakan data non-keungan yaitu 9 indikator aktivitas operasional perusahaan yang dikembangkan oleh Mahoney, et al. (1963).

Berdasarkan definisi uraian kinerja perusahaan diatas, maka variabel kinerja perusahaan dalam penelitian ini diukur dengan menggunakan dua dimensi yaitu dimensi aspek pelanggan (4 indikator) yang dikembangkan oleh Govindarajan (1986) dan telah diuji validitas dan reabilitas oleh Bisbe dan Otley (2004). Sedangkan dimensi aspek aktivitas manajemen (9 indikator) yang dikembangkan oleh Mahoney, et al. (1963) dan telah diuji validitas dan realibilitas oleh Soobaroyen dan Poorundersing (2008). Uraian masing-masing dimensi seperti berikut:

a. Dimensi kinerja aspek pelanggan. Kinerja berdasarkan aspek pelanggan merupakan informasi yang disajikan dalam bentuk non-keuangan yaitu 
informasi customer satisfaction, customer retention, customer acquasition, dan growth of market share.

b. Dimensi kinerja aspek aktivitas manajemen. Kinerja berdasarkan aspek aktivitas operasional/ manajemen perusahaan yaitu planning, investigating, coordinating, evaluating, supervising, staffing, negotiating, representing dan overall performance.

\section{Analisis Data}

Ghozali (2011) menyatakan analisis jalur dapat digunakan jika pengaruh variabel independen terhadap dependen bersifat searah (recursive) dan variabel diukur dengan data minimal skala interval. Berdasarkan pandangan diatas, penelitian ini menggunakan analisis jalur (path analysis) untuk menguji hipotesis. Berikut ini disajikan tahapan pengujian hipotesis penelitian menggunakan struktural analisis pengaruh antar variabel adalah seperti gamabar 1 berikut ini.

Gambar 1: Struktural Pengaruh Antar Variabel Penelitian.

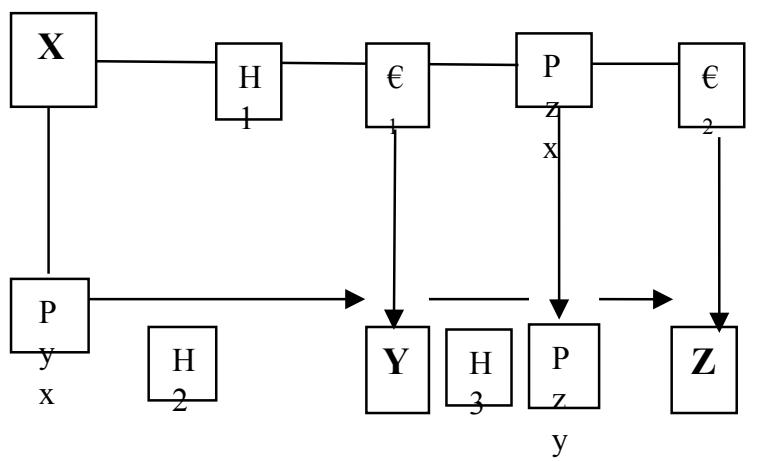

\section{HASIL PENELITIAN DAN PEMBAHASAN} Statistik Deskriptif

Pengujian validitas dan reliabilitas variabel. Uji validitas instrumen dalam penelitian ini menggunakan analisis faktor dan uji reliabilitas instrumen menggunakan Cronbach's Alpha untuk setiap indikatornya. Hasil uji untuk variabel audit internal menunjukkan nilai Kaiser-Meyer-Olkin Measure of Sampling Adequacy $=0,864$ dan nilai Cronbach's Alpha $=0,942$. Untuk variabel penggunaan sistem akuntansi manajemen nilai Kaiser-Meyer-Olkin Measure of Sampling Adequacy $=0,898$ dan nilai Cronbach's Alpha $=0,961$, sedangkan untuk variabel kinerja perusahaan memperoleh nilai Kaiser-MeyerOlkin Measure of Sampling Adequacy $=0,932$ dan nilai Cronbach's Alpha $=0,967$. Artinya semua instrumen penelitian ini merupakan alat pengumpulan data yang valid dan reliable sehingga dapat digunakan dalam penelitian dan akan memberikan hasil penelitian yang dapat dipercaya dan konsisten (Kaiser dan Rice, 1974, dan Nunnally, 1978).

Pengujian korelasi antar variabel. Hasil penelitian menunjukkan bahwa variabel audit internal berkorelasi positif dan signifikan dengan semua dimensi penggunaan sistem akuntansi manajemen dan kinerjan perusahaan. Artinya jika aktivitas audit internal dan penggunaan sistem akuntansi manajemen ditingkatkan maka akan meningkat pula pencapaian tujuan perusahaan. Hubungan antara audit internal dengan penggunaan sistem akuntansi manajemen adalah $0,711(0,01)$ dan hubungan antara penggunaan sistem akuntansi manajemen dengan kinerja perusahaan adalah $0,599(0,01)$. Hubungan ini masuk kategori tingkat sedang seperti terlihat pada tabel 2 dibawah ini.

\section{Tabel 2: Analisis Korelasi antar Variabel Hasil Pengujian Hipotesis}

Hipotesis satu (H1) menyatakan audit internal berpengaruh terhadap kinerja perusahaan. Hasil uji menunjukkan bahwa $R$ square $\left(\mathrm{r}^{2}\right)$ adalah 0,359, yang dapat digunakan untuk menaksir besarnya pengaruh audit internal terhadap kinerja perusahaan yaitu Koefisien Diterminasi (KD) sebesar 35,90\%, sisanya sebesar $64,10 \%$ diduga dipengaruhi oleh faktor lain yang tidak diteliti. Apabila dilihat dari uji-F menunjukkan nilai yang signifikan pada 0,000 , sedangkan uji-t menunjukkan nilai beta $0,589(0,01)$.

\begin{tabular}{|c|c|c|c|c|c|c|c|c|}
\hline Variabel & & $\mathrm{x}$ & $\mathrm{Y}_{1}$ & $\mathrm{Y}_{2}$ & $\mathrm{Y}_{3}$ & $\mathrm{Y}_{4}$ & $\mathrm{Z}_{1}$ & $\mathrm{Z}_{2}$ \\
\hline Audit internal $(X)$ & & 1 & & & & & & \\
\hline Informasi broad-scope $\left(\mathrm{Y}_{\mathrm{I}}\right)$ & & $0,605^{* *}$ & 1 & & & & & \\
\hline Informasi timeliness ( $\left.\mathrm{Y}_{2}\right)$ & $0,649^{* *}$ & $0,708^{* *}$ & 1 & & & & & \\
\hline Informasi aggregation $\left(\mathrm{Y}_{3}\right)$ & & $0,604 * *$ & $0,595 * *$ & $0,637^{* *}$ & 1 & & & \\
\hline Informasi integration $\left(\mathrm{Y}_{4}\right)$ & $0,641^{* *}$ & $0,583 * *$ & $0,708^{* *}$ & $0,691^{* *}$ & 1 & & & \\
\hline Kinerja aspek pelanggan (ZI) & & $0,531^{* *}$ & $0,601 * *$ & $0,565^{* *}$ & $0,551^{* *}$ & $0,620^{* *}$ & 1 & \\
\hline Kinerja aspek manajemen $\left(\mathrm{Z}_{2}\right)$ & & $0,588^{* *}$ & $0,569^{* *}$ & $0,700^{* *}$ & $0,565^{* *}$ & $0,677^{* *}$ & $0,764 * *$ & 1 \\
\hline $\begin{array}{l}{ }^{* *} \text { ) Signifikansi pada } 0,01 \\
\text { (two-tailed) }\end{array}$ & & & & & & & & \\
\hline
\end{tabular}

Artinya model prediksi yang digunakan dalam penelitian ini disebut goodness of fit model. Dengan demikian dapat disimpulkan bahwa $\mathrm{H} 1$ diterima yaitu variabel audit internal berpengaruh positif dan signifikan terhadap kinerja perusahaan.

Hasil uji hipotesis satu konsisten dengan hasil penelitian sebelumnya seperti hasil penelitian Holzinger (1999) dan Zarkasyi (2007). Hasil penelitian ini juga mendukung teori yang dibangun dan kembangkan oleh IIA (2011), Elder, et al. (2012), Ratliff, et al. (1996) dan Sawyers dan Ditenhover (2003). Baik secara teoritis maupun berdasarkan hasil penelitian empiris telah membuktikan bahwa penerapan audit internal yang profesional dan konsisten akan berdampak positif terhadap pencapaian dan peningkatan kinerja perushaaan. Misalnya pelayanan dan kepuasan konsumen meningkat, perencanaan dan penyusunan program kerja tepat sasaran, koordinasi dan supervisi operasional menjadi kondusif dan sebagainya.

Hipotesis dua (H2) menyatakan audit internal berpengaruh terhadap penggunaan sistem akuntansi manajemen (usefulness of management accounting system). Hasil uji menunjukkan bahwa $R$ square $\left(\mathrm{r}^{2}\right)$ adalah 0,506, yang dapat digunakan untuk menaksir besarnya pengaruh audit internal terhadap penggunaan sistem akuntansi manajemen yaitu Koefisien Diterminasi (KD) sebesar 50,60\%, sisanya sebesar $49,40 \%$ diduga dipengaruhi oleh faktor lain yang tidak diteliti. Apabila dilihat dari uji-F menunjukkan nilai yang signifikan pada 0,000 , sedangkan uji-t menunjukkan nilai beta 1,124 $(0,01)$. Artinya model prediksi yang digunakan dalam 
penelitian ini disebut goodness of fit model. Dengan demikian dapat disimpulkan bahwa $\mathrm{H} 2$ diterima yaitu variabel audit internal berpengaruh positif dan signifikan terhadap penggunaan sistem akuntansi manajemen (SAM).

Hasil uji hipotesis dua membuktikan bahwa mendukung hasil penelitian terdahulu seperti Ziegenfuss (1994) dan Kusmayadi (2005). Hasil penelitian ini juga sejalan dengan buku-buku teks misalnya yang dikembangkan oleh Horngren, Foster dan Datar (2012) dan Horngren, Sunden dan Stratton (1996). Audit internal memberikan peranan yang besar terhadap penggunaan sistem akuntansi manajemen sehingga terjadi peningkatan kualitas informasi yang disajikan kepada manajemen. Laporan hasil audit internal mengandung berbagai informasi diantaranya informasi keuangan dan nonkeuangan yang relevan dan terkini kondisi operasional perusahaan. Hal ini dapat meningkatkan kualitan informasi akuntansi manajemen.

Hasil penelitian juga menjelaskan bahwa audit internal berpengaruh positif dan signifikan terhadap dimensi variabel penggunaan sistem akuntansi manajemen (dimensi informasi Broadscope, Timeliness, Levels of Aggregation dan Integrative Nature) dan variabel kinerja perusahaan (dimensi aspek pelanggan dan aktivitas manajemen). Laporan hasil audit menyediakan informasi terkini sehingga kualitas informasi akuntansi manajemen meningkat. Manajemen menggunakan informasi yang berkualitas untuk membuat kebijakan dan teknik operasional perusahaan yang tepat sasaran, penetapan harga jual dan penerapan rantai nilai dan pasokan bahan baku sehingga pertumbuhan penjualan naik, operasional kondusif, koordinasi efektif dan resiko manajemen dapat diminimalkan. Secara terperinci disajikan dalam tabel 3 dibawah ini.

Tabel 3: Pengaruh Audit Internal terhadap Dimensi Penggunaan Sistem Akuntansi Manajemen (SAM) dan Kinerjan Perusahaan.

Hipotesis tiga(H3) menyatakan penggunaan sistem akuntansi manajemen (usefulness of management accounting system) berpengaruh terhadap kinerja perusahaan. Hasil uji menunjukkan bahwa $R$ square $\left(\mathrm{r}^{2}\right)$ adalah 0,523, yang dapat digunakan untuk menaksir besarnya pengaruh penggunaan sistem akuntansi manajemen terhadap kinerja perusahaan yaitu Koefisien Diterminasi (KD) sebesar 52,30\%, sisanya sebesar $47,70 \%$ diduga dipengaruhi oleh faktor lain yang tidak diteliti. Apabila dilihat dari uji-F menunjukkan nilai yang signifikan pada 0,000 ,

\begin{tabular}{lcccccc}
\hline \multicolumn{1}{c}{ Variabel } & $\begin{array}{c}\text { Variabel } \\
\text { Independen } \\
\text { Dependen }\end{array}$ & $\begin{array}{c}\text { Audit } \\
\text { Internal }\end{array}$ & Sguare & F & Sig & t-test \\
\hline Informasi Broadscope & $0,245 * *$ & $36,70 \%$ & 48,032 & 0,000 & 6,93 \\
Informasi Timeliness & $0,169 * *$ & $42,10 \%$ & 60,358 & 0,000 & 7,769 \\
Informasi Aggregation & $0,516^{* *}$ & $36,50 \%$ & 47,761 & 0,000 & 6,911 \\
Informasi Integration & $0,184 * *$ & $41,10 \%$ & 57,91 & 0,000 & 7,61 \\
$\begin{array}{l}\text { Kinerja Aspek } \\
\text { Pelanggan }\end{array}$ & $0,217 * *$ & $28,20 \%$ & 32,627 & 0,000 & 5,712 \\
$\begin{array}{l}\text { Kinerja Aspek } \\
\begin{array}{l}\text { Manajemen } \\
\text { **) Signifikansi pada }\end{array}\end{array}$ & $0,372 * *$ & $34,60 \%$ & 43,864 & 0,000 & 6,623 \\
0,01 (two-tailed $)$ & & & & & \\
\hline
\end{tabular}

sedangkan uji-t menunjukkan nilai beta $0,449(0,01)$. Artinya model prediksi yang digunakan dalam penelitian ini disebut goodness of fit model. Dengan demikian dapat disimpulkan bahwa $\mathrm{H} 3$ diterima yaitu variabel penggunaan sistem akuntansi manajemen berpengaruh positif dan signifikan terhadap kinerja perusahaan. Hasil penelitian ini mendukung hasil penelitian Soobaroyen dan Poorundersing (2008) dan Duh, et al. (2009). Hasil penelitian ini juga sejalan dengan teori yang dikembangkan oleh Horngren, et al. (2012) dan Brandon dan Drtina (1997). Kualitan informasi yang digunakan manajemen bisa menentukan baik buruknya kebijakan yang diterapkan sehingga berdampak terhadap sukses tidaknya rencana pertumbuhan penjualan, kualitas produk, kondusivitas operasional perusahan dan sebagainya.

Selanjutnya, perhitungan pengaruh total (total effect) yaitu pengaruh langsung (direct effect) dan pengaruh tidak langsung (indirect effect) audit internal terhadap kinerja perusahaan atau melalui perantara penggunaan sistem akuntansi manajemen (SAM) seperti berikut; pengaruh langsung audit internal terhadap kinerja perusahaan sebesar $(0,359)^{2}$ $=12,89 \%$ positif dan signifikan. Pengaruh tidak langsung audit internal terhadap kinerja perusahaan melalui penggunaan sistem akuntansi manajemen $(\mathrm{SAM})$ sebesar $(0,359 \times 0,523 \times 0,711)=13,35 \%$ positif dan signifikan. Sehingga diperoleh pengaruh total adalah $26,24 \%$ positif dan signifikan. Jadi dapat disimpulkan bahwa audit internal berpengaruh positif dan signifikan terhadap penggunaan sistem akuntansi manajemen (SAM) dan berdampak positif pada peningkatan kinerja perusahaan, misalnya perencanaan dan pengendalian opersional efektifi, pelayanan dan kepusanaan konsumen meningkat, dan seterusnya.

\section{KESIMPULAN DAN SARAN}

Hasil penelitian empiris ini menyatakan bahwa audit internal berpengaruh positif dan signifikan terhadap kinerja perusahaan. Kemudian penggunaan sistem akuntansi manajemen (SAM) berpengaruh positif dan signifikan terhadap peningkatan kinerja perusahaan. Selanjutnya audit internal juga berpengaruh positif dan signifikan terhadap penggunaan sistem akuntansi manajemen (SAM) dan dampaknya pada kinerja perusahaan. Auditor internal memiliki peran yang besar dalam mensukseskan jalannya operasi perusahaan yang law enforcement, bersama manajemen (agent) menjunjung tinggi sikap kehati-hatian, governance process dan fairness. Laporan temuan audit dan rekomendasinya juga menyajikan berbagai informasi bagi manajemen tentang operasional perusahaan kondisi saat ini maupun masa mendatang, misalnya masalah sistem pengendalian manajemen resiko, sistem akuntansi keuangan, sistem akuntansi manajemen dan sistem informasi manajemen. Hal ini nantinya akan menyebabkan meningkatnya kepuasan pelanggan, jumlah pelanggan, kondusifnya operasi perusahaan, 
akhirnya kinerja perusahaan meningkat. Sehingga audit internal juga berpengaruh positif dan signifikan terhadap penggunaan sistem akuntansi manajemen (SAM) dan dampaknya pada kinerja perusahaan.

Saran. Berdasarkan hasil penelitian diatas, saran penulis kepada manajemen (agent) yaitu: (1) diharapkan manajemen senantiasa membentuk organ-organ satuan pengawas intern dan akuntan manajemen dalam struktur organisasi yang sah dan konsisten; (2) optimalkan fungsi auditor internal dan akuntan manajemen agar tersedianya informasi yang berkualitas sehingga operasi perusahaan tepat guna dan tepat sasaran, akhirnya kinerja perusahaan meningkat.

\section{DAFTAR PUSTAKA}

Abubakar, M. 2011. Kekayaan: aset BUMN. Kompas. Senin 14 Maret 2011. Jakarta.

Bachtiar, E. 2012. Kasus-kasus Etika Bisnis dan Profesi. Edisi Pertama. Jakarta: penerbit Salemba Empat.

Bahaudin, M.A. 2011. Ekspektasi direksi terhadap kontribusi internal auditor: peran dan fungsi SPI dalam transformasi Pertamina. Seminar Nasional Internal Audit. YPIA. Batam.

Barry, J.P., et al. 1994. Internal audit: an Australia profile. Managerial Auditing Journal, 9(3): 13-19.

Belkaoui, A. 2002. Behavioral Management Accounting. First edition. USA: Greenwood Publishing Group, Inc.

Bisbe, J. dan Otley, D.T. 2004. The effects of the interactive use of management control systems on product innovation. Accounting, Organizations and Society 29: 709-737.

Brandon, C.H. dan Drtina, R.E. 1997. Management Accounting: Strategy and Control. Thirdth edition. New York: McGraw-Hill Companies, Inc.

Chenhall, R.H. dan Morris, D. 1986. The impact of structure, environment and interdependence on the perceived usefulness of management accounting systems. The Accounting Review, 61(1): 16-35.

Crockett, J.R. 1988. Operational Audit: Preparing the Controller. Internal Auditing. 3(3): 46-53.

Daniri, M. A. 2005. Good Corporate Governance: Konsep dan Penerapannya dalam Konteks Indonesia. Edisisi pertama. Jakarta: Gloria Printing.

Duh, R.R., Xiao, J.Z. dan Chow, C.W. 2009. Chinese firm's use of management accounting and controls: facilitator, impediments and performance effects. Journal of International Accounting Research. 8(1).

Elder, R.J., Beasley, M.S. dan Arens, A.A. 2010. Auditing and Assurance Services: an Integrated Approach. New Jersey: Thirteenth edition. Pearson Education, Inc.

Ghozali, I. 2011. Aplikasi Analisis Multivariat Dengan Program SPSS. Edisi 5. Semarang: BP. Undip.

Glover, S.M., et al. 1998. Internal auditing poll, data survey, software, technological change and statistical data many countries. Internal Auditing Journal, 55(4): 212-219.

Govindarajan, V. 1984. Appropriateness of accounting data in performance evaluation: an empirical examination of environmental uncertainty as an intervening variable. Accounting, Organizations and Society 9(2): 125-135.

1986. Impact of participation in the budgetary process on managerial attitudes and performance: universalistic and contingency perspectives. Decision Science 17(4): 496-516.

Gul, F.A. 1991. The effect of management accounting systems and environmental uncertainty on small business manager's performance. Accounting and Business Research. 22(85): 57-61.

Hansen, D.R. dan Mowen, M.M. 2005. Management Accounting. $7^{\text {th }}$ edition. Cincinati-Ohio: South Western Publishing Co.

Holzinger, A. 1999. The new internal auditing function. Internal Auditing Journal, 56(3): 187-203.

Horngren, C.T., Datar, S.M. dan Rajan, M.V. 2012. Cost Accounting: A Managerial Emphasis. Fourteenth edition. New Jersey: Pearson Education, Inc.

, Sundem, G.L. dan Stratton, W.O. 1996. Introduction to Management Accounting. Tenth edition. New Jersey: Prentice-Hall, Inc.

Hoque, Z. 2004. Strategic Management Accounting. Second edition. USA: Spiro Press.

Kaiser,H,F. dan Rice, J. 1974. Littlejiffy, mark IV. Educational and Psychological Measurement. 34: 111-117.

Kusumayadi, D. 2005. Pengaruh audit operasional terhadap penerapan akuntansi pertanggungjawaban dan implementasi strategi serta dampaknya pada kinerja perusahaan. Disertasi. Universitas Padjadjaran Bandung. Tidak dipublikasikan.

Lane, D.C. 1983. The operational audit: a business appraisal approach to improved operations and profitability. The Journal of the Operational research Society 34 (10) 961-978.

Maher, M.W. dan Ramanan, R. 1988. Does internal auditing improve managerial performance. Management Accounting 69 (9) 54-56.

Mahoney, T.A., Jerdee, T.H. dan Carrol, S.J. 1963. Development of Managerial Performance: a Research Approach. Cincinnati: South western Publishing.

Nunnally, J.C. 1978. Psychometric theory. New York: McGraw Hill, Inc.

Pratolo, S. 2006. Pengaruh audit manajemen, komitmen manajer pada organisasi, pengendalian intern terhadap penerapan prinsip-prinsip good corporate governance dan kinerja perusahaan. Disertasi. Program Pascasarjan Unpad (tidak dipublikasikan). 
Ratliff, R.L., Wallace, W.A., Sumners, G.E., McFarland, W.G. dan Loebbecke, J.K. 1996. Internal Auditing: Principles and Techniques. Second edition. Florida: Altamonte Springs.

Robbins, S.P. dan Coulter, M. 2009. Management. $10^{\text {th }}$ edition. New Jersey: Pearson Education, Inc.

Sawyer, B.L. dan Dittenhover, A.M. 2003. Sawyer's Internal Auditing. $5^{\text {th }}$ edition. Florida: The Institute of Internal Auditor. USA.

Soobarroyen, T. dan Poorundersing, B. 2008. The effectiveness of management accounting systems: evidence from functional managers in a developing country. Managerial Auditing Journal. 23(2):187-219.

The Institute of Internal Auditors (IIA). 2011. The Professional Practices Framework. First Edition. Florida: The IIA Research Foundation.
The National Association of Accountants. 1981. Definition of Management Accounting: Statement \# IA. New York.

Zarkasyi, M. W. 2007. The role of the audit committee and internal audit in the implementation of good corporate governance and its impact on state-owned enterprise performance in Indonesia. Economic Journal, 22(1): 13-29.

Ziegenfuss, D.E., Singhapadki, A. dan Martinson, O.B. 1994. Do internal auditors and management accountants have different ethical philosophies. Managerial Auditing Journal 9(1): 4-12.

http://bumn.indonesia.blogspot.com, daftar nama perusahaan BUMN, Tanggal 20 Mei 2011. 